\title{
Fabrication of a solid catalyst using coal fly ash and its utilization for producing biodiesel
}

\author{
Young Wook Go, Sung Ho Yeom ${ }^{\dagger}$ \\ Department of Biochemical Engineering, Gangneung-Wonju National University, Gangneung 25457, Republic of Korea
}

\begin{abstract}
To recycle raw fly ash (RFA), a waste from thermal power plants, it was used to prepare solid catalysts which have many advantages compared with homogenous catalysts. When biodiesel was produced from soybean oil using RFA, only $1.2 \%$ of biodiesel conversion was obtained. A metal hydroxide, $\mathrm{NaOH}, \mathrm{KOH}$ or $\mathrm{Ca}(\mathrm{OH})_{2}$, was mixed with the acid-treated fly ash (ATFA), and the mixture was calcined at $700^{\circ} \mathrm{C}$ for 3 $\mathrm{h}$ to prepare the solid catalyst. The solid catalyst prepared by mixing ATFA with $\mathrm{NaOH}$, designated as SC-Na, showed a better performance than those prepared by mixing ATFA with $\mathrm{KOH}$ or $\mathrm{Ca}(\mathrm{OH})_{2}$, respectively. The optimal mass ratio of ATFA with $\mathrm{NaOH}$ was $1: 3$, at which the proportion of $\mathrm{Na}_{2} \mathrm{O}$ increased to $60.2 \%$ in SC-Na, and $97.8 \%$ of biodiesel conversion was achieved under optimal reaction conditions (2 $\mathrm{w} \%$ SC-Na relative to oil and $5 \mathrm{~mL}-\mathrm{methanol} / \mathrm{g}$-oil at $50^{\circ} \mathrm{C}$ for $4 \mathrm{~h}$ ). Finally, a batch operation was repeatedly carried out to test the feasibility of reusing the solid catalyst, and more than $96 \%$ biodiesel conversion was stably achieved for the third round of operations. This study shows that RFA was successfully recycled to solid catalysts through a simple preparation method, and the solid catalyst was reused for the production of biodiesel with high conversion.
\end{abstract}

Keywords: Biodiesel, Fly ash, Optimum conditions, Reuse, Solid catalyst

\section{Introduction}

Biodiesel is a renewable and carbon-neutral fuel made by the transesterification of mostly vegetable oil and animal fat using methanol [1, 2]. A catalyst is essentially required for transesterification to accelerate the chemical reaction, and chemical catalysts such as acidic and alkaline compounds, and biological catalysts such as enzymes and whole cells have been extensively used [3, 4]. Among these catalysts, chemical catalysts such as sodium hydroxide $(\mathrm{NaOH})$ and sulfuric acid $\left(\mathrm{H}_{2} \mathrm{SO}_{4}\right)$ have been extensively used in the industry as well as lab-scale studies because they can produce biodiesel at high reaction rates and their prices are relatively cheap [1]. Although biological catalysts have the advantage of achieving high biodiesel conversion under a mild reaction temperature, they are costly and can be easily deactivated with methanol [5]. Moreover, they require a substantially longer reaction time than chemical catalysts [3, 5].

Despite their extensive use, chemical catalysts cannot be reused because they are dispersed homogenously in the reaction medium and become non-separable. Accordingly, the processes using these chemical catalysts require them to be introduced repeatedly at every batch of operation; they require large amounts of water for the neutralization and washing of biodiesel, which inevitably causes the discharge of a large amount of wastewater [6, 7]. In addition, the crude glycerol, a major by-product that can be converted to valuable chemicals, is of low quality and value or requires costly purification by distillation. [8]. Contrary to homogenous chemical catalysts, heterogeneous solid catalysts have a significant advantage of enabling the possible reuse and easy separation from the reaction mixture, which would substantially decrease catalyst requirement and wastewater discharge [6, 7]. In addition, high purity biodiesel and glycerol could be easily separated from the reaction mixture [8].

A large amount of fly ash, one of the residues generated during coal combustion, is discharged from thermal power plants. Approximately 8 million tons of fly ash is produced annually in Korea, and approximately $70 \%$ of it is recycled for use as an additive to cement and construction materials; most of the remains are land-filled [9]. Researchers have used fly ash as the adsorbent for phosphate [10, 11], dye [12, 13], and heavy metal ions [14-16]. Another method of recycling fly ash is as a catalyst
This is an Open Access article distributed under the terms of the Creative Commons Attribution Non-Commercial License (http://creativecommons.org/licenses/by-nc/3.0/) which permits unrestricted non-commercial use, distribution, and reproduction in any medium, provided the original work is properly cited.

Copyright (C) 2019 Korean Society of Environmental Engineers
Received January 11, 2018 Accepted August 27, 2018

${ }^{\dagger}$ Corresponding author

Email: shyeom@gwnu.ac.kr

Tel: +82-33-640-2406 Fax: +82-33-641-2410

ORCID: 0000-0002-9851-6069 
for chemical reactions, because it contains various kinds of metal ions that possibly act as catalysts for chemical reactions [17, 18]. Many researchers have attempted the preparation of zeolite from coal fly ash for biodiesel production but the process of manufacturing zeolite is quite complex [19, 20]. Few researchers have previously focused on the optimization of reaction conditions for biodiesel production using the catalysts derived from fly ash. Therefore, a simple preparation method for the solid catalyst is required, and the optimization of the reaction conditions for biodiesel production using the solid catalyst should be investigated.

In this study, raw fly ash (RFA), a waste from thermal power plants, was recycled to prepare solid catalysts for biodiesel production. Unlike conventional complicated methods, a simple process for preparation of the solid catalyst using RFA was proposed, and optimal reaction conditions for biodiesel production using this solid catalyst were determined. Finally, the feasibility of reuse of the solid catalyst, one of the main advantages of the solid catalyst, was discussed by demonstrating a repeated-batch mode operation for biodiesel production.

\section{Materials and Methods}

\subsection{Materials}

RFA was donated by a thermal power plant located in the city of Gangneung. A scanning electron microscope (SEM) image of RFA was taken by a FE-SEM (S-4700, Hitachi, Japan). The size distribution of RFA was determined using a particle size analyzer (MasterSizer 2000, Malvern, UK). Soybean oil was purchased from a domestic supplier (CJ, Korea). Methanol (Daejung, Japan), sodium hydroxide (Showa, Japan), and sulfuric acid (Showa, Japan) were of the analytical grade. The standard materials for GC analysis (methyl palmitate, methyl oleate, methyl linoleate, methyl stearate, and methyl heptadecanoate) were purchased from Sigma-Aldrich, USA.

\subsection{Preparation of Solid Catalyst}

To remove impurities and increase the surface area and pore volume, RFA was pretreated with an acidic solution [21, 22]. Based on our literature survey [22] and preliminary experiments, we used a mixture of $3 \mathrm{M} \mathrm{HCl}$ and $4 \mathrm{M} \mathrm{H}_{2} \mathrm{SO}_{4}$ in the same volumetric ratio. RFA was mixed with the acid solution in a mass ratio of $1: 2$, and incubated at $60^{\circ} \mathrm{C}$ for $1.5 \mathrm{~h}$ at $300 \mathrm{rpm}$ (SI-600R, Jeio Tech, Korea). After the incubation, the acid-treated fly ash (ATFA) was washed with distilled water twice, and dried in an oven at $105^{\circ} \mathrm{C}$ for 24 h. To increase the alkaline or alkaline earth metal oxide content in the solid catalyst, ATFA was mixed with $\mathrm{NaOH}$, potassium hydroxide $(\mathrm{KOH})$ or calcium hydroxide $\left(\mathrm{Ca}(\mathrm{OH})_{2}\right)$ in various mass ratios depending on the experimental design. The mixture was placed in an electric furnace (Lenton, UK) at $700^{\circ} \mathrm{C}$ for $1 \mathrm{~h}$ for calcination. The solid catalysts prepared by mixing ATFA with $\mathrm{NaOH}, \mathrm{KOH}$, and $\mathrm{Ca}(\mathrm{OH})_{2}$ were designated the SC-Na, SC-K, and SC-Ca, respectively. The resultant solid catalyst was ground in a mortar and pestle if necessary, and was used for biodiesel production. The compositions of RFA, ATFA, and solid catalysts were analyzed using X-ray fluorescence (ZSX100e, Rigaku, Japan). The procedure for the preparation of the solid catalyst is presented in Fig. 1.

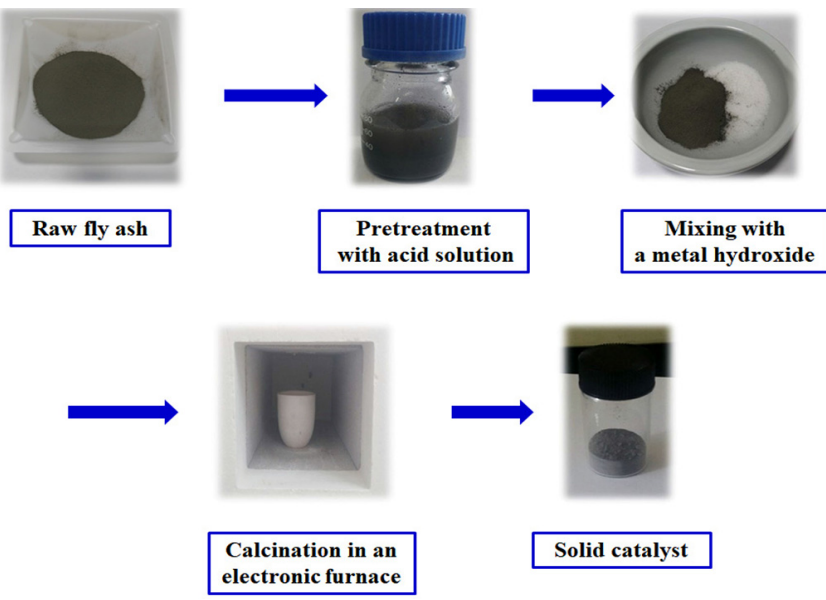

Fig. 1. Procedure for the preparation of solid catalysts.

\subsection{Analysis}

The free fatty acid (FFA) content of soybean oil was determined according to the AOCS Official Method Ca5a-40 [23, 24]. After $0.7 \mathrm{~g}$ of sample was introduced into a $150-\mathrm{mL}$ flask, $10 \mathrm{~mL}$ of $95 \%$ ethanol and 3 drops of $1 \%$ phenolphthalein solution $11 \mathrm{~g}$ of phenolphthalein in $100 \mathrm{~mL}$ of ethanol) were added into the flask, and then titrated using $0.13 \mathrm{~N}$ sodium hydroxide solution. The FFA content was calculated as the percentage of oleic acid, as instructed in the AOAC Official Method, using Eq. (1) [23, 24].

FFAs as oleic acid $(\%)=\frac{\text { alkaline volume }(\mathrm{mL}) \times \text { alkali normality }}{\text { mass of sample }(\mathrm{g})} \times 28.2$

Biodiesel conversion was determined using a GC (7820A, Agilent, USA) apparatus equipped with a FID detector and HP-5 column (30 $\mathrm{m} \times 0.32 \mathrm{~mm} \times 0.25 \mu \mathrm{m}$ film thickness) [1, 2]. Each biodiesel component was identified using GC-Mass $(6890$ GC/5973i MSD, Agilent, USA) [1, 2]. The GC chromatogram of biodiesel produced from soybean oil exhibited five distinct peaks including the internal standard peak as shown in Fig. 2. We made calibration curves for each FAMEs individually and used them for the quantification of biodiesel. The calibration curves for the each compound were regularly checked and minutely adjusted to ensure the accuracy of biodiesel conversion.

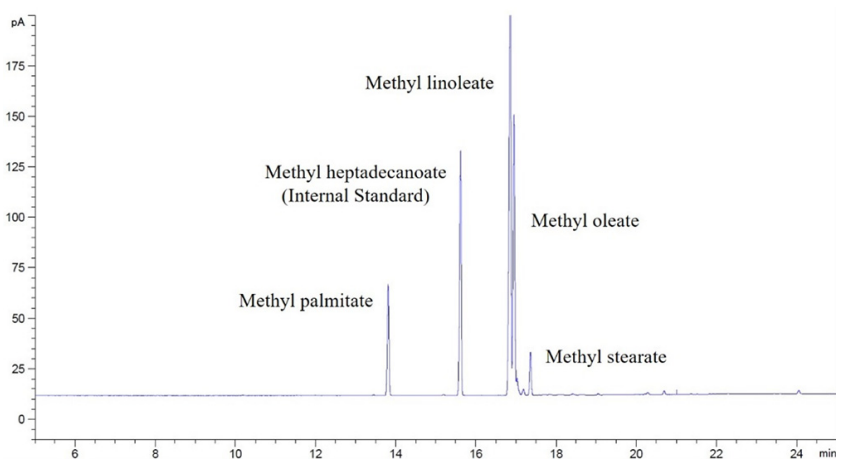

Fig. 2. GC chromatogram of biodiesel produced from soybean oil using solid catalyst in this study. 


\subsection{Biodiesel Production}

One gram of fresh soybean oil was placed in a $30-\mathrm{mL}$ vial containing methanol and solid catalyst, whose amounts varied according to the experimental design. Biodiesel production was carried out in a shaking water bath (BS-21, Jeio Tech, Korea). The initial reaction conditions were: $3 \mathrm{w} \%$ of solid catalyst relative to soybean oil, $10 \mathrm{~mL}$-methanol/g-oil, $60^{\circ} \mathrm{C}, 8 \mathrm{~h}$, and $300 \mathrm{rpm}$. These conditions were roughly the averages of values obtained in our previous studies, which were as follows: $1.5 \mathrm{~mL}$-methanol/g-lipid, $45^{\circ} \mathrm{C}$, $9 \mathrm{~h}$, and $200 \mathrm{rpm}$ for the alkaline catalyst [2], and $20 \mathrm{~mL}$-methanol/g-lipid, $70^{\circ} \mathrm{C}, 8 \mathrm{~h}$, and $300 \mathrm{rpm}$ for the acidic catalyst [1]. The amount of solid catalyst ( $3 \mathrm{w} \%$ ) used was based on previous studies that used the zeolite catalyst [20, 25].

After the reaction was completed, $2 \mathrm{~mL}$ of distilled water was added to the vial and it was shaken vigorously. The mixture was centrifuged at 4,000 rpm for $30 \mathrm{~min}$ (Gyro 1236MG, Gyrozen, Korea) for phase separation. The upper layer was separated and dried in a fume hood for $24 \mathrm{~h}$ to obtain biodiesel. The biodiesel was analyzed by GC-MS to determine its composition and by GC to determine biodiesel conversion [1, 2].

\subsection{Reuse of the Solid Catalyst for Biodiesel Production}

The solid catalyst was reused in a repeated-batch mode operation. After biodiesel was produced in a batch operation under the opti- mal conditions determined in this study, the bottle was kept for $1 \mathrm{~h}$ to allow the solid catalyst to settle down. After the entire reaction mixture was separated using a syringe (Kovax-Syringe, Korea Vaccine, Korea), $1 \mathrm{~g}$ of fresh soybean oil and methanol, whose amount was determined in this study, was added to the bottle containing solid catalyst used in the first round of operation. This procedure was repeatedly performed to produce biodiesel.

\section{Results and Discussion}

\subsection{Characterization of Raw Fly Ash}

The RFA obtained from a thermal power plant was spherical in shape, as shown in Fig. 3(a). Its average diameter was $20 \mu \mathrm{m}$ (Fig. 3(b)). The composition of RFA was also determined as shown in Table 1, which indicates that its most abundant compounds were $\mathrm{SiO}_{2}$ (50.5\%), $\mathrm{Al}_{2} \mathrm{O}_{3}$ (26.5\%), and $\mathrm{Fe}_{2} \mathrm{O}_{3}$ (9.2\%), together accounting for $86.2 \%$ of RFA. The total composition of alkali and alkaline earth metal oxides (AAEMOs), extensively used as catalysts for biodiesel production [2, 26], was only $8.3 \%$, which included $1.1 \%$ of $\mathrm{Na}_{2} \mathrm{O}, 1.6 \%$ of $\mathrm{K}_{2} \mathrm{O}$, and $5.6 \%$ of $\mathrm{CaO}$. The $\mathrm{SiO}_{2}$ content in RFA in this study was much lower than that in other studies, in which it was 59.8\% [20], 60.5\% [6], and 68.8\% [19]; the AAEMO content was less than $5 \%$ in all these studies.
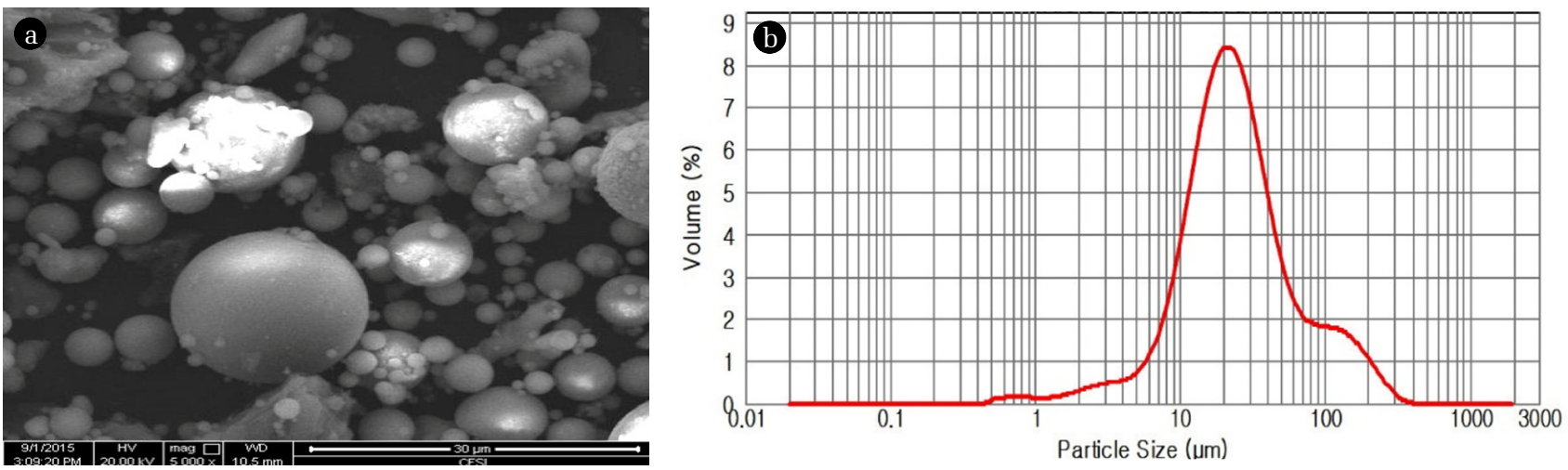

Fig. 3. The characteristics of raw fly ash. (a) SEM image, (b) size distribution.

Table 1. Change in Composition of Coal Fly Ash after Acid Treatment and Solid Catalyst Development

\begin{tabular}{|c|c|c|c|c|c|}
\hline \multirow{2}{*}{ Component } & \multirow{2}{*}{ Raw fly ash } & \multirow{2}{*}{ Fly ash after acid-treatment } & \multicolumn{3}{|c|}{ Solid catalyst ${ }^{\mathrm{a}}$} \\
\hline & & & SC-Na & SC-K & SC-Ca \\
\hline $\mathrm{SiO}_{2}$ & 50.5 & 60.8 & 28.4 & 29.3 & 28.9 \\
\hline $\mathrm{Al}_{2} \mathrm{O}_{3}$ & 26.5 & 22.2 & 3.6 & 4.5 & 3.1 \\
\hline $\mathrm{Fe}_{2} \mathrm{O}_{3}$ & 9.2 & 6.2 & 1.4 & 1.2 & 1.1 \\
\hline $\mathrm{CaO}$ & 5.6 & 2.0 & 1.3 & 1.1 & 61.7 \\
\hline $\mathrm{MgO}$ & 2.2 & 0.7 & 0.4 & 0.5 & 0.2 \\
\hline $\mathrm{TiO}_{2}$ & 1.6 & 2.0 & 1.4 & 0.8 & 1.3 \\
\hline $\mathrm{K}_{2} \mathrm{O}$ & 1.6 & 1.7 & 0.4 & 58.7 & 0.7 \\
\hline $\mathrm{Na}_{2} \mathrm{O}$ & 1.1 & 0.7 & 60.2 & 0.3 & 0.2 \\
\hline Others & 1.8 & 3.7 & 2.9 & 3.6 & 2.8 \\
\hline
\end{tabular}

${ }^{a}$ The composition was determined at the mass mixing ratio of metal hydroxide to acid-treated fly ash, 3:1. 


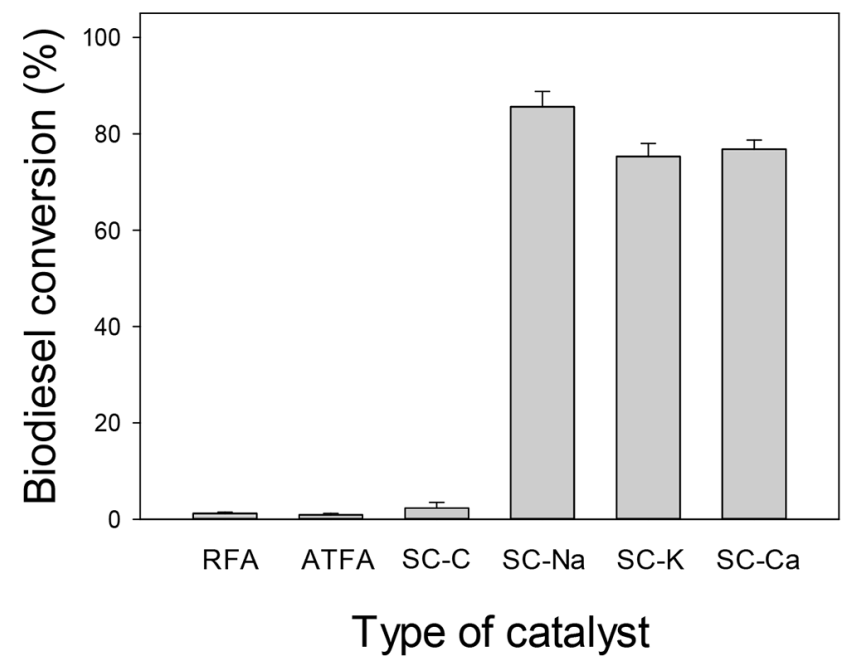

Fig. 4. Effect of catalyst type on biodiesel conversion. (Reaction conditions: $3 \%(\mathrm{w} / \mathrm{w})$ solid catalyst, $10 \mathrm{~mL}-\mathrm{methanol} / \mathrm{g}-\mathrm{oil}, 60^{\circ} \mathrm{C}, 8 \mathrm{~h}$, and $300 \mathrm{rpm})$

To investigate the possibility of using RFA as the catalyst for biodiesel production, biodiesel was produced from soybean oil using RFA. As shown in Fig. 4, only 1.2\% of biodiesel conversion occurred. Because the FFA content in soybean oil used in this study was determined to be only $0.15 \%$, the alkaline character of RFA may not be the cause of the low biodiesel conversion $[27,28]$. Rather, the low proportion of AAEMOs $(0.25 \%$ relative to soybean oil), 3 w\% of solid catalyst along with $8.3 \%$ of AAEMOs, could be the reason for the low biodiesel conversion. Therefore, RFA in its original form could not be used as a solid catalyst for biodiesel production.

\subsection{Preparation of Solid Catalyst}

After the treatment of RFA with acid, its composition was noticeably changed, as shown in Table $1 . \mathrm{SiO}_{2}$ increased significantly by $20.4 \%$ (from $50.5 \%$ to $60.8 \%$ ) while $\mathrm{Al}_{2} \mathrm{O}_{3}$ and $\mathrm{Fe}_{2} \mathrm{O}_{3}$ were decreased by $16.2 \%$ (from $26.5 \%$ to $22.2 \%$ ) and $32.7 \%$ (from $9.2 \%$ to $6.2 \%$ ), respectively. In particular, the AAEMO content was decreased by approximately $50 \%$, from $8.3 \%$ to $4.4 \%$. Biodiesel was produced using this ATFA, and biodiesel conversion was as low as $0.9 \%$, as shown in Fig. 4 . These results may imply again that biodiesel conversion appeared to be related to the AAEMO content. To verify this assumption, ATFA was mixed with one of the three metal hydroxides, $\mathrm{NaOH}, \mathrm{KOH}$ or $\mathrm{Ca}(\mathrm{OH})_{2}$, in a mixing ratio of $1: 2$, to increase the proportion of one of the AAEMOs, and the solid catalyst was prepared according to the procedure shown in Fig. 1. As indicated in Table 1, the content of $\mathrm{Na}_{2} \mathrm{O}, \mathrm{K}_{2} \mathrm{O}$, and $\mathrm{CaO}$ were significantly increased, while that of $\mathrm{SiO}_{2}$ was significantly decreased to approximately 29\%. For example, when $\mathrm{NaOH}$ was mixed with ATFA, the $\mathrm{SiO}_{2}$ content was decreased from $60.8 \%$ to $28.4 \%$, while $\mathrm{Na}_{2} \mathrm{O}$ content increased from $1.1 \%$ to $60.2 \%$. Biodiesel was produced using these solid catalysts, which were compared with a control solid catalyst (SC-C) prepared using the same procedure without mixing any metal hydroxide. While biodiesel conversion was $2.3 \%$ for the SC-C,
Table 2. Effect of the Mass Mixing Ratio of Metal Hydroxide to Acid Treated-Fly Ash on Biodiesel Conversion

\begin{tabular}{cccc}
\hline \multirow{2}{*}{$\begin{array}{c}\text { Mass mixing ratio } \\
\text { (metal hydroxide:fly ash ) }\end{array}$} & \multicolumn{3}{c}{ Biodiesel conversion (\%) } \\
\cline { 2 - 4 } & SC-Na & SC-K & SC-Ca \\
\hline $1: 1$ & 73.2 & 62.1 & 68.2 \\
$2: 1$ & 85.6 & 75.3 & 76.8 \\
$3: 1$ & 92.8 & 88.7 & 85.1 \\
$4: 1$ & 93.4 & 89.2 & 85.7 \\
$5: 1$ & 93.7 & 90.5 & 83.4 \\
\hline
\end{tabular}

the solid catalysts exhibiting high $\mathrm{Na}_{2} \mathrm{O}$ (SC-Na), $\mathrm{K}_{2} \mathrm{O}$ (SC-K), and $\mathrm{CaO}$ (SC-Ca) content showed biodiesel conversions of $85.6 \%$, $75.3 \%$, and $76.8 \%$, respectively, as shown in Fig. 4. Therefore, it can be inferred that the solid catalysts prepared in this study could be used for biodiesel production.

Various solid catalysts were prepared using different mixing ratios of metal hydroxide to ATFA, and evaluated as solid catalysts for biodiesel production. As shown in Table 2, as the ratio increased, biodiesel conversion generally increased until the mixing ratio was 3 . When the mixing ratio was further increased to 4 , biodiesel conversion was barely increased from the value observed with the mixing ratio 3 , irrespective of the kind of metal hydroxide used. Accordingly, the optimal mixing ratio for metal hydroxide to ATFA was found to be 3 in this study. Among the solid catalysts, the performance of SC-Na was better than that of SC-K and SC-Ca at all the mixing ratios. Therefore, we used SC-Na, prepared in the mixing ratio of $3: 1$, in the subsequent experiments.

\subsection{Optimum Conditions for Biodiesel Production}

Catalyst concentration, methanol loading, temperature, and reaction time are the main parameters for biodiesel production [1, 2]. Agitation is another parameter to be considered for heterogeneous catalysts. The agitation speed should be high enough to enable the solid catalyst to float; otherwise, the solid catalyst precipitates in the reaction mixture. The effects of the catalyst concentration (0.1-5\%), methanol loading (1-15 mL-methanol/g-oil), reaction time (1-10 h), reaction temperature $\left(30-60^{\circ} \mathrm{C}\right)$, and agitation speed (50-600 rpm) on biodiesel conversion were investigated, and optimal conditions were determined using the one factor at a time approach. The initial reaction was carried out with $10 \mathrm{~mL}-\mathrm{methanol} / \mathrm{g}$-oil, at $60^{\circ} \mathrm{C}, 8 \mathrm{~h}$, and $300 \mathrm{rpm}$.

\subsubsection{Effect of catalyst concentration on biodiesel production}

Most of the studies using heterogeneous catalysts required a larger amount of catalyst to be used than that for homogenous chemical catalysts. In our previous study, $0.5 \% \mathrm{NaOH}$ or $0.2 \% \mathrm{H}_{2} \mathrm{SO}_{4}$ was found to be the optimal catalyst concentration for biodiesel production using lipids from waste coffee grounds and sewage sludge, respectively [1, 2]. Researchers used $3 \mathrm{w} \%$ or more catalyst relative to oils for the zeolite catalyst [6, 20, 29]. In this section, we added different amounts of SC-Na for biodiesel production, and the results were presented in Fig. 5. When the amount of SC-Na relative to soybean oil was $0.1 \mathrm{w} \%$, biodiesel conversion was only $13.7 \%$. When the amount of SC-Na was increased to 0.5 $\mathrm{w} \%$ and $1.0 \mathrm{w} \%$, biodiesel conversion also increased to $35.6 \%$ 


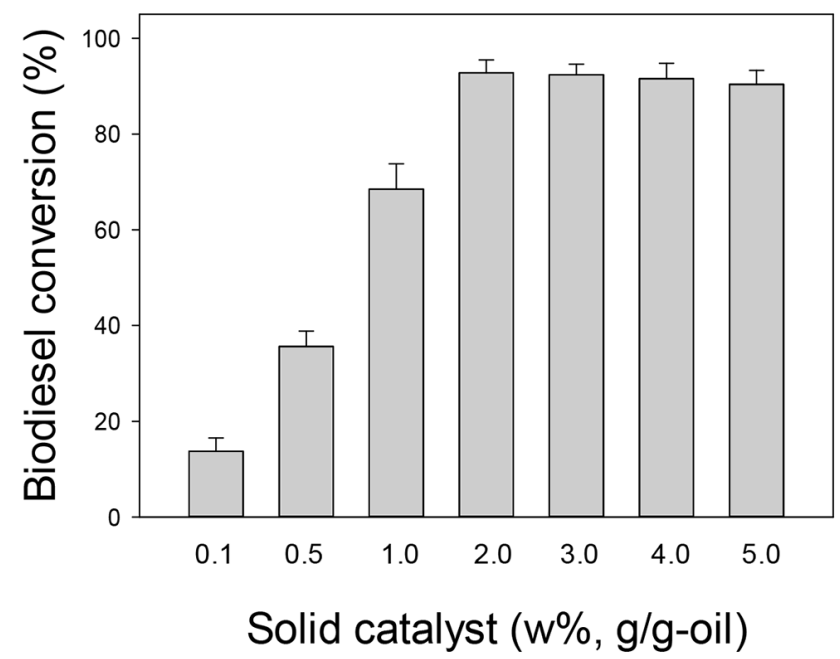

Fig. 5. Effect of solid catalyst loading on biodiesel conversion. (Reaction conditions: $10 \mathrm{~mL}$-methanol/g-oil, $60^{\circ} \mathrm{C}, 8 \mathrm{~h}$, and $300 \mathrm{rpm}$ )

and $68.5 \%$, respectively. The biodiesel conversion increased until $2.0 \mathrm{w} \%$ of SC-Na (92.8\%) but no more increase in biodiesel conversion was observed at $3.0 \mathrm{w} \%$ of SC-Na. Therefore, we inferred that the optimum solid catalyst concentration was $2.0 \mathrm{w} \%$ relative to oil content.

\subsubsection{Effect of methanol loading on biodiesel production}

The stoichiometric equation of transesterification requires 3 molar ratio of methanol to soybean oil (MRMS). However, an excess amount of methanol has been used to enhance the miscibility of the reactants, shift the equilibrium towards a high biodiesel conversion, and allow its phase separation from the glycerol formed [7, 30]. For the sake of convenience, methanol loading was defined as the methanol volume per mass of oil instead of MRMS [1-5]. As presented in Fig. 6, biodiesel conversion was significantly influenced by methanol loading, and was only $35.3 \%$ at the lowest methanol loading of $1 \mathrm{~mL}-$ methanol/g-oil. The biodiesel conversion increased as the amount of methanol increased,

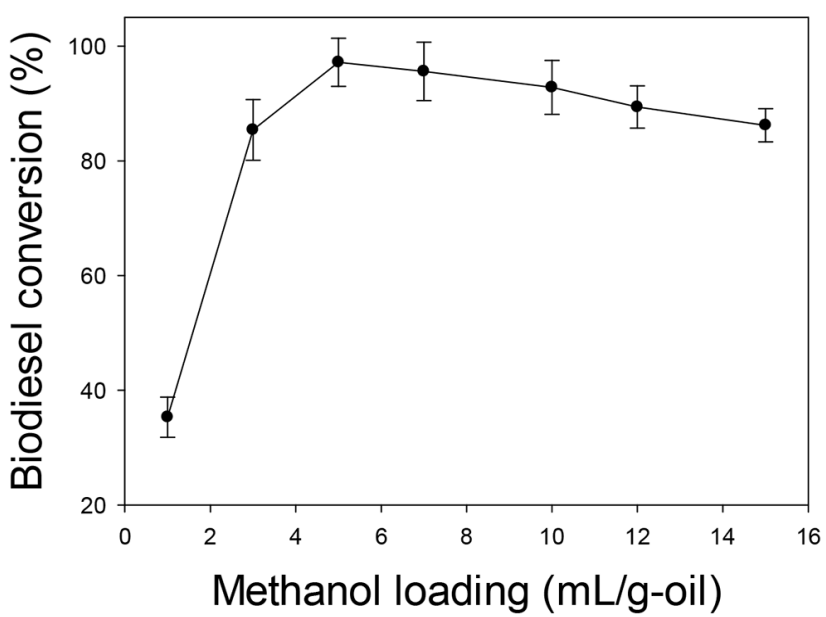

Fig. 6. Effect of methanol loading on biodiesel conversion. (Reaction conditions: $2 \mathrm{w} \%$ solid catalyst, $60^{\circ} \mathrm{C}, 8 \mathrm{~h}$, and $300 \mathrm{rpm}$ ) and the maximum biodiesel conversion was $97.2 \%$ with 5 mL-methanol/g-oil. When the methanol loading was further increased, the biodiesel conversion became rather decreased, i.e., biodiesel conversions were $92.8 \%$ and $86.2 \%$ with the use of $10 \mathrm{~mL}-\mathrm{methanol} / \mathrm{g}$-oil and $15 \mathrm{~mL}$-methanol/g-oil, respectively. This decrease may be due to the dilution of the solid catalyst, which had been also observed when the homogenous or ionic liquid catalysts were used [1,31]. Therefore, a methanol loading of $5 \mathrm{~mL}$-methanol/g-soybean oil was determined to be the optimal value.

\subsubsection{Effect of reaction time, temperature, and agitation speed on biodiesel production}

Because the product of the temperature and reaction time may imply the amount of energy that was input into the reaction, we investigated the combined effect of temperature and reaction time on biodiesel conversion. Through this approach, we could explore the possibility of lowering energy input without it affecting biodiesel conversion. Catalyst concentration, methanol loading, and agitation speed were $2 \mathrm{w} \%, 5 \mathrm{~mL}-\mathrm{methanol} / \mathrm{g}$-oil, and 300 rpm, respectively. As seen in Fig. 7, biodiesel conversion was rapidly increased at $60^{\circ} \mathrm{C}$; it was $72.4 \%$ after $1 \mathrm{~h}$ and $95.0 \%$ after $3 \mathrm{~h}$. At $50^{\circ} \mathrm{C}$, although the increase in the rate of conversion was lower than that at $60^{\circ} \mathrm{C}$, biodiesel conversion was $94.6 \%$ at $3 \mathrm{~h}$, and reached its maximum value $(97.8 \%)$ in $4 \mathrm{~h}$, which was very similar to the value observed at $60^{\circ} \mathrm{C}$. At $40^{\circ} \mathrm{C}$, the biodiesel conversion was $85.3 \%$ after $4 \mathrm{~h}$, and the increase in biodiesel conversion was sluggish thereafter. At $30^{\circ} \mathrm{C}$, biodiesel conversion continuously increased with time, but stayed constant at around $80 \%$ after $8 \mathrm{~h}$. Based on these results, we determined that the optimum temperature and reaction time to be $50^{\circ} \mathrm{C}$ and $4 \mathrm{~h}$, respectively. The energy input $\left(50^{\circ} \mathrm{C}\right.$ and 4 h) observed in this study is comparable to the following energy inputs in previous studies using soybean oil and solid catalyst from coal fly ash: $65^{\circ} \mathrm{C}$ and $8 \mathrm{~h}$ to achieve $81.2 \%$ of biodiesel conversion [32] and $65^{\circ} \mathrm{C}$ and $2 \mathrm{~h}$ to achieve $95.5 \%$ of biodiesel conversion [33].

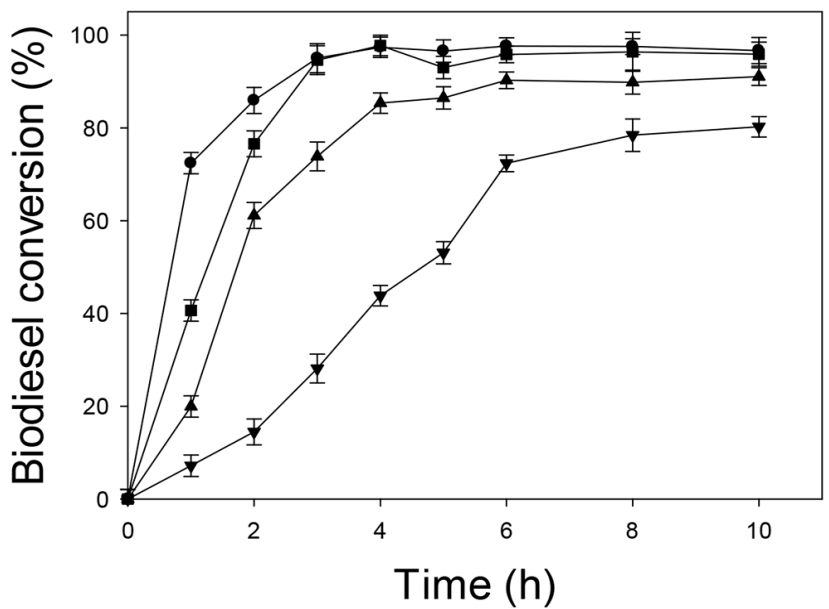

Fig. 7. Effect of reaction temperature and time on biodiesel conversion.

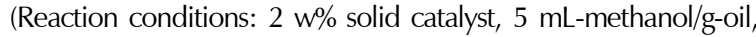
and $300 \mathrm{rpm} . \mathbf{0}: 60^{\circ} \mathrm{C}, \boldsymbol{\square}: 50^{\circ} \mathrm{C}, \boldsymbol{\Delta}: 40^{\circ} \mathrm{C}, \boldsymbol{\nabla}: 30^{\circ} \mathrm{C}$ ) 
Finally, we investigated the effect of agitation speed on biodiesel conversion. We set the following reaction conditions: $2 \%$ catalyst concentration, $5 \mathrm{~mL}$-methanol/g-oil, $50^{\circ} \mathrm{C}$, and $3 \mathrm{~h}$. The agitation speed varied between 50-800 rpm. Although the effect of agitation speed on biodiesel conversion was significant, more than $96 \%$ of biodiesel conversion was obtained as long as the agitation speed was over $200 \mathrm{rpm}$, as can be seen in Fig. 8. Therefore, the optimal conditions for biodiesel production using heterogeneous solid catalyst (Na-SC) were finally determined to be $2 \%$ catalyst concentration, $5 \mathrm{~mL}$-methanol $/ \mathrm{g}$-oil, $50^{\circ} \mathrm{C}, 4 \mathrm{~h}$, and 200 rpm.

One of the main advantages of solid catalysts is that it can be used repeatedly, because of which we can save on the catalyst, readily separate highly pure biodiesel and glycerol, and decrease wastewater discharge significantly. We produced biodiesel using SC-Na in the manner of repeated batch operation as described

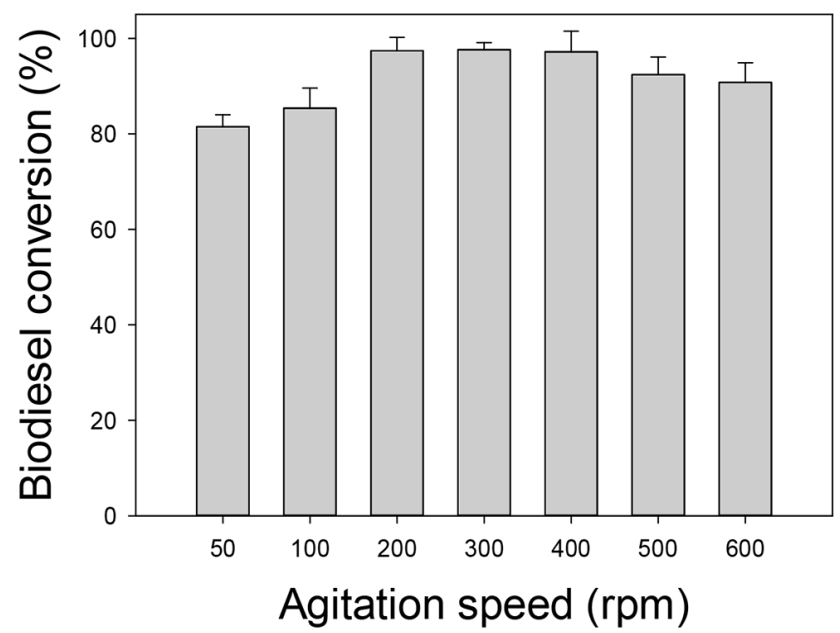

Fig. 8. Effect of agitation speed on biodiesel conversion. (Reaction conditions: $2 \mathrm{w} \%$ solid catalyst, $5 \mathrm{~mL}-\mathrm{methanol} / \mathrm{g}-\mathrm{oil}, 50^{\circ} \mathrm{C}$, and $4 \mathrm{~h}$ )

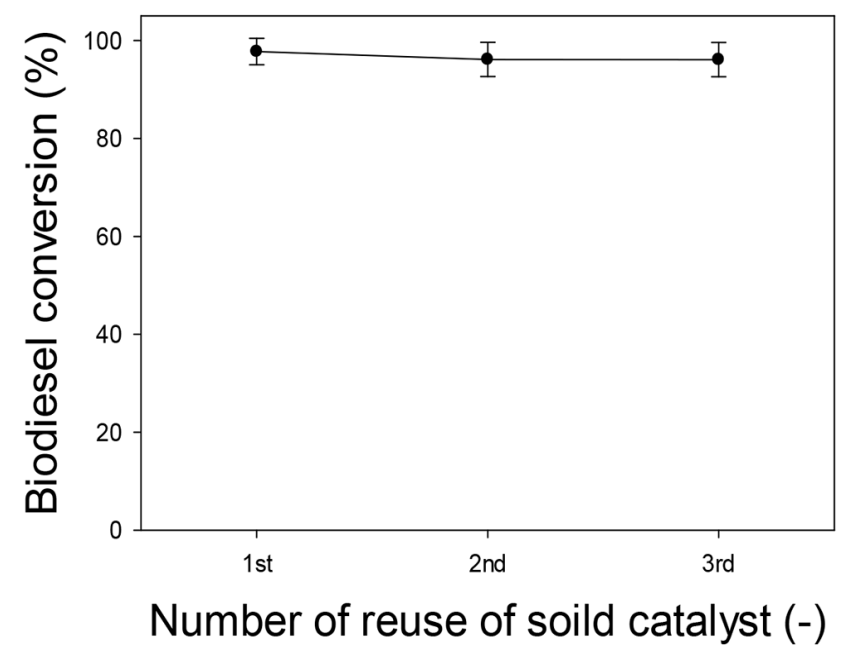

Fig. 9. Reuse of solid catalyst for biodiesel production. (Reaction conditions: $2 \mathrm{w} \%$ solid catalyst, $5 \mathrm{~mL}$-methanol/g-oil, $50^{\circ} \mathrm{C}, 4 \mathrm{~h}$, and $200 \mathrm{rpm})$ in the Materials and Methods section. As shown in Fig. 9, biodiesel conversion was stably over $96 \%$ until the 3rd round $(97.8 \%$ for the first round and $96.1 \%$ for the third round), which showed that it was feasible to further reuse the solid catalyst for biodiesel production.

\section{Conclusions}

RFA is recycled to prepare solid catalysts which have many advantages over conventional chemical catalysts such as $\mathrm{H}_{2} \mathrm{SO}_{4}$ and $\mathrm{NaOH}$. The total composition of the alkali and alkaline earth metal oxides (AAEMOs; $\mathrm{Na}_{2} \mathrm{O}, \mathrm{K}_{2} \mathrm{O}$, and $\mathrm{CaO}$ ) in RFA were only $8.3 \%$, which led to as low as $1.2 \%$ of biodiesel conversion. After acid treatment of RFA, it was mixed with $\mathrm{NaOH}, \mathrm{KOH}$ or $\mathrm{Ca}(\mathrm{OH})_{2}$ to enhance AAEMOs. SC-Na that was prepared by mixing acid-treated fly ash (ATFA) with $\mathrm{NaOH}$ showed better performance than SC-Ca and SC-K catalysts. The optimum mass ratio of ATFA with $\mathrm{NaOH}$ was $1: 3$, at which the proportion of $\mathrm{Na}_{2} \mathrm{O}$ increased to $60.2 \%$ in SC-Na, and $97.8 \%$ of biodiesel conversion was achieved at the optimum reaction conditions $(2 \mathrm{w} \%$ solid catalyst, 5 $\mathrm{mL}$-methanol/g-oil, $50^{\circ} \mathrm{C}$, and $4 \mathrm{~h}$ ). Until the third round of batch reactions, more than $96 \%$ of biodiesel conversion had been stably achieved.

This study showed that a solid catalyst for biodiesel production was successfully manufactured using RFA from a thermal power plant. The application of the solid catalyst to feedstock with high FFA content such as sewage sludge and microalga also need to be investigated, which will be explored in future studies.

\section{Acknowledgments}

This work was supported by the Basic Science Research Program through the National Research Foundation of Korea (NRF) funded by the Ministry of Education (NRF-2015R1D1A1A01060540 and 2018R1D1A1B07051113). The authors greatly appreciate this support.

\section{References}

1. Pansuwan S, Yeom SH. Optimization of a two-step biodiesel production process comprised of lipid extraction from blended sewage sludge and subsequent lipid transesterification. Biotechnol. Bioprocess Eng. 2016;21:551-560.

2. Go YW, Yeom SH. Statistical analysis and optimization of biodiesel production from waste coffee grounds by a two-step process. Biotechnol. Bioprocess Eng. 2017;22:440-449.

3. Jeon DJ, Yeom SH. Two-step bioprocess employing whole cell and enzyme for economical biodiesel production. Korean J. Chem. Eng. 2010;27:1555-1559.

4. Kyeong JS, Yeom SH. Preparation of immobilized whole cell biocatalyst and biodiesel production using a packed-bed bioreactor. Bioprocess Biosyst. Eng. 2014;37:2189-2198.

5. Jeon DJ, Yeom SH. Comparison of methods for preventing methanol inhibition in enzymatic production of biodiesel. 
Korean J. Chem. Eng. 2011;28:1420-1426.

6. Xiang Y, Wang L, Jiao Y. Ultrasound strengthened biodiesel production from waste cooking oil using modified coal fly ash as catalyst. J. Environ. Chem. Eng. 2016;4:818-824.

7. Viriya-empikul N, Krasae P, Nualpaeng W, Yoosuk B, Faungnawakij K. Biodiesel production over Ca-based solid catalysts derived from industrial wastes. Fuel 2012;92:239-244.

8. Russbueldt BME, Hoelderich WF. New rare earth oxide catalysts for the transesterification of triglycerides with methanol resulting in biodiesel and pure glycerol. J. Catal. 2010;271: 290-304.

9. Maeng JH, Kim TY, Cho HN, Kim EY. Minimizing environmental impact of ash treatment in thermal power plants (II). Korea Environ. Inst. Rep. 2015;2015-02-02.

10. Li Y, Liu C, Luan Z, et al. Phosphate removal from aqueous solutions using raw and activated red mud and fly ash. J. Hazard. Mater. 2006;137:374-383.

11. Pengthamkeerati P, Satapanajaru T, Chularuengoaksorn P. Chemical modification of coal fly ash for the removal of phosphate from aqueous solution. Fuel 2008;87:2469-2476.

12. Wang S, Boyjoo Y, Choueib A, Zhu ZH. Removal of dyes from aqueous solution using fly ash and red mud. Water Res. 2005;39:129-138.

13. Wang S, Boyjoo Y, Choueib A. A comparative study of dye removal using fly ash treated by different methods. Chemosphere 2005;60:1401-1407.

14. Visa M. Synthesis and characterization of new zeolite materials obtained from fly ash for heavy metals removal in advanced wastewater treatment. Powder Technol. 2016;294:338-347.

15. Lee CH, Kam SK, Lee MG. Removal characteristics of Sr ion by Na-A zeolite synthesized using coal fly ash generated from a thermal power plant. J. Environ. Sci. Int. 2017;26:363-371.

16. Zhang Q, Lin B, Hong J, Chang CH. Removal of ammonium and heavy metals by cost-effective zeolite synthesized from waste quartz sand and calcium fluoride sludge. Water Sci. Technol. 2017;75:587-597.

17. Xuan X, Yue C, Li S, Yao Q. Selective catalytic reduction of NO by ammonia with fly ash catalyst. Fuel 2003;82:575-579.

18. Khatri C, Rani A. Synthesis of a nano-crystalline solid acid catalyst from fly ash and its catalytic performance. Fuel 2008;87:2886-2892.

19. Manique MC, Lacerda LV, Alves AK, Bergmann CP. Biodiesel production using coal fly ash-derived sodalite as a heterogeneous catalyst. Fuel 2017;190:268-273.

20. Bhandari R, Volli V, Purkait MK. Preparation and characterization of fly ash based mesoporous catalyst for transesterification of soybean oil. J. Environ. Chem. Eng. 2015;3: 906-914.

21. Sarbak Z, Wachowiak MK. Porous structure of waste fly ashes and their chemical modifications. Powder Technol. 2002;123: 53-58.

22. Anuwattana R, Khummongko P. Conventional hydrothermal synthesis of Na-A zeolite from cupola slag and aluminum sludge. J. Hazard. Mater. 2009;166:227-232.

23. AOAC International. Official methods of analysis. 20th ed. George W, Latimer Jr., eds. Rockville: AOAC International; 2016.

24. Rukunudin IH, White PJ, Bern CJ, Bailey TB. A modified method for determining free fatty acids from small soybean oil sample sizes. J. Am. Oil Chem. Soc. 1998;75:563-568.

25. Babajide O, Musyoka N, Petrik L, Ameer F. Novel zeolite Na-X synthesized from fly ash as a heterogeneous catalyst in biodiesel production. Catal. Today 2012;190:54-60.

26. Marchetti JM, Miguel VU, Errazu AF. Possible methods for biodiesel production. Renew. Sust. Energ. Rev. 2007;11:1300-1311.

27. Freedman B, Butterfield RH, Pryde EH. Transesterification kinetics of soybean oil. J. Am. Chem. Soc. 1986;63:1375-1380.

28. Phan AN, Phan TM. Biodiesel production from waste cooking oils. Fuel 2008;87:3490-3496.

29. Liu X, He H, Wang Y, Zhu S, Piao X. Transesterification of soybean oil to biodiesel using $\mathrm{CaO}$ as a solid base catalyst. Fuel 2008;87:216-221.

30. Demirbas A. Comparison of transesterification methods for production of biodiesel from vegetable oils and fats. Energ. Convers. Manage. 2008;49:125-130.

31. Han X, Yan W, Hung CT, et al. Transesterification of soybean oil to biodiesel by tin-based Brønsted-Lewis acidic ionic liquid catalysts. Korean J. Chem. Eng. 2016;33:2063-2072.

32. Bhandari R, Volli V, Purkait MK. Preparation and characterization of fly ash based mesoporous catalyst for transesterification of soybean oil. J. Environ. Chem. Eng. 2015;3:906-914.

33. Wei Z, Xu C, Li B. Application of waste eggshell as low-cost solid catalyst for biodiesel production. Bioresour. Technol. 2009;100:2883-2885. 